\title{
乳幼児のマイコプラズマ肺炎の臨床的検討
}

\author{
武田 紳江 ${ }^{1,2)}$, 黑崎 知道 ${ }^{1)}$, 石和田稔彦 ${ }^{2)}$, 河野 陽一 ${ }^{2)}$ \\ 1) 千葉市立海浜病院小児科 \\ 2) 千葉大学大学院医学研究院小児病態学
}

\begin{abstract}
要旨：乳幼児のマイコプラズマ肺炎の臨床像を検討するため, 5 歳以下 43 例を 6 歳以上 40 例と 比較した。6 歳以上に比べ 5 歳以下では咳嗽の性状は湿性咳嗽が $90.0 \%$ を占め, 肺副雑音も $83.7 \%$ に聴取し, 末梢血白血球数も $10,000 / \mu \mathrm{L}$ 以上を示す症例がみられ成人市中肺炎診療ガイドライン に記載されている非定型肺炎の特徵とは異なる臨床像を認めた。また 5 歳以下の乳幼児では細気 管支炎, 気管支喘息発作を合併する割合や，ウイルスや細菌の混合感染の割合が 6 歳以上より高 率に認められ, 臨床像が成人と異なる要因と考えられた。年齢による微粒子凝集（PA）法による 抗体価上昇の遅延は認めないが, 診断基準を満たす抗体価上昇に 15 日以上要した症例がみられた。 以上より 5 歳以下のマイコプラズマ肺炎の臨床像は非典型的であり, 急性期に診断ができる感度 のよい検査法もないため, 早期に有用な検査法の確立が望まれる。
\end{abstract}

\section{The clinical characteristics of Mycoplasma pneumoniae pneumonia in children younger than 6 years old}

\author{
Nobue Takeda ${ }^{1,2)}$, Tomomichi Kurosaki ${ }^{1)}$, Naruhiko Ishiwada ${ }^{2)}$, Yoichi Kohno ${ }^{2)}$ \\ 1) Department of Pediatrics, Chiba Municipal Kaihin Hospital \\ ${ }^{2)}$ Department of Pediatrics, Chiba University Graduate School of Medicine
}

Summary: The characteristics of Mycoplasma pneumoniae pneumonia in adult are nonproductive cough, lack of rales, and the white blood cell counts are $<10,000 / \mu \mathrm{L}$. The aim of this study was to investigate the clinical characteristics of hospitalized cases with $M$. pneumoniae pneumonia in children younger than 6 years old. A retrospective analysis of 83 children( $0-15$ years old) at the Chiba Municipal Kaihin Hospital in 2005 was performed. Serologic diagnosis was made based on a 4 -fold rise or single titers $>/=1: 640$, which were measured by particle aggulutination (PA) test. Children younger than 6 years old accounted for $51.8 \%$ (43 cases) of the cases. Among the children younger than 6 years old, $90.0 \%$ had productive cough. Rales and altered breath sounds could be heared in $83.7 \%$ and white blood cell counts were elevated higher than $10,000 / \mu \mathrm{L}$ in $31.8 \%$ of patients without athma and bacterial infection. $37.2 \%$ of patients complicated bronchiolitis or infectious asthma. $41.9 \%$ of patients had found to have mixed bacterial infection and/or viral infection. In conclusion, the clinical characteristics $M$. pneumoniae pneumonia in children younger than 6 years old differ evidently from those of adults because of mixed bacterial infection and/or viral infection, and complicated bronchiolitis or infectious asthma. 


\section{はじめに}

マイコプラズマ感染症の診断は, 現在市中病 院では抗体価測定による血清学的診断が中心で ある。しかし急性期に診断基準を満たす抗体価 の上昇が得られないことが多いため, 回顧的診 断にならざるを得ない場合が多い。このためマ イコプラズマ感染症の診断は困難なことが多 く, 臨床症状から推測し治療を開始しているの が現状である。成人市中肺炎診療ガイドライン （表 1）では, 細菌性肺炎と非定型肺炎の鑑別点 を挙げてスコアリングし推定する方法が記載さ れている。鑑別点として挙げられているのは, 年歯令, 臨床症状および末梢血白血球数である。 今回成人市中肺炎診療ガイドラインに鑑別点と して挙げられている項目を含め 5 歳以下の乳幼 巟のマイコプラズマ肺炎の臨床的特徴を検討し た。

\section{対象と方法}

\section{1. 対 象}

2006 年 4 月から 2007 年 3 月までの期間に千 葉市立海浜病院小児科に肺炎のため入院した小 児 291 例（5 歳以下 221 例， 6 歳以上 70 例）の うち, 臨床症状や血液検査所見より主治医がマ イコプラズマ肺炎を疑いマイコプラズマ抗体価
を測定し診断した 5 歳以下 43 例， 6 歳以上 40 例計 83 例を対象とした。マイコプラズマ肺炎 の診断は胸部レントゲン上浸潤影を認め主治医 が肺炎と診断し，かつ微粒子凝集（PA）法にて 単血清で 640 倍以上もしくはぺア血清で 4 倍以 上の上昇を認める場合とした。

\section{2. 方 法}

今回 6 歳以上の学童と対比させながら 5 歳以 下の乳幼児の以下の点について入院カルテより 後方視的に検討を行った。

(1) 入院症例の背景

i）年齢分布

ii）平均入院病日と抗菌薬の前投薬の有無 : 病日は発熱を認めた日を 1 病日とした。平均入 院病日は発熱がなく病日が不明の 2 歳の 1 例は 除外した。また抗菌薬の投与期間，コンプライ アンスの検討は行っていない。

iii）合併症：本検討では入院カルテによる後 方視的検討のため，気管支喘息発作の定義を喘 鳴を伴う呼吸困難を反復した既往があり，かつ 入院中に喘鳴を伴う呼吸困難や胸部聴診上 wheeze や rhonchi を聴取することから主治医 が喘息発作と診断し，テオフィリンの内服やア ミノフィリンの持続静注またはステロイドの内 服や静注にて軽快した症例とした。喘息疑いは 今までに既往はないが上記の所見と治療を行い

表 1 細菌性肺炎と非定型肺炎の鑑別（成人市中肺炎診療 ガイドライン, 2005.10 より)
1. 年齢 60 歳未満
2. 基礎疾患がない, あるいは軽微
3. 頑固な咳がある
4. 胸部聴診上所見がそしい
5. 痰がない, あるいは, 迅速診断法で原因菌が証明されない
6. 末梢血白血球数が $10,000 / \mu \mathrm{L}$ 末満である

上記 6 項目を使用した場合

6 項目中 4 項目以上合致した場合

(感度 $77.9 \%$, 特異度 $93 \%$ )

1 〜 5 までの 5 項目を使用した場合 5 項目中 3 項目以上を合致した場合 (感度 $83.9 \%$, 特異度 $87 \%$ )
非定型肺炎疑い

非定型肺炎 
軽快した症例である。細気管支炎の診断は喘鳴 や胸部聴診上 rhonchi を認めるが, 今まで既往 がなく上記気管支喘息の治療を行わず軽快した 症例とした。

(2) 入院時の臨床症状と血液検査所見

i）咳嗽の性状

ii）胸部聴診所見

iii）末梢血白血球数, CRP：白血球数は喘息 発作を合併した症例を除く 5 歳以下 30 例, 6 歳 以上 40 例について検討した。また白血球数, CRP は細菌感染を含む場合と除外した場合につ いて検討した。

(3) ウイルス, 細菌の合併率

入院中にウイルス感染が疑われる一部の症例 にウイルス迅速抗原検査の種類を選択して施行 した。本検討におけるウイルス感染例とは迅速 抗原検査陽性例のみである。すなわち RS ウイ ルス, インフルエンザウイルス, アデノウイル スの 3 種類のみであり, RS ウイルスはチェッ ク RSV ${ }^{\mathrm{TM}}$ (SA Scientific, Inc.), インフルエンザ ウイルスは BD Flu エグザマン ${ }^{\mathrm{m}}$ (日本ベクト ン・ディッキンソン株式会社), アデノウイル スはチェック $\mathrm{Ad}^{\mathrm{TM}}$ (SA Scientific, Inc.) を使用 した。細菌培養検査は入院時に喀痰が採取でき た症例は喀痰培養検査を行い, 痰がからまず喀 痰が採取できない症例は鼻咽頭培養を行った。 今回細菌感染ありと判断した症例は, 喀痰の鏡 検にて Gecklerの分類で 4 群 5 群の喀痰が採取 でき, かつ洗浄喀痰培養により常在菌 1+（培地 の面積の 3 分の 1 発育) 以下で原因菌が $2+$ (培 地の面積の 3 分の 2 発育) 以上検出, もしくは 原因菌が純培養で $1+$ 以上検出された場合であ る。Moraxella catarrhalis は上記基準に加え鏡 検で貪食像陽性例を原因菌とした。

(4) マイコプラズマ抗体価（PA法）の上昇 と病日

年齢による抗体価の上昇に有意差が認められ るか検討するため, 入院時, 7 病日, 10 病日の
時点での 640 倍以上の症例数を比較した。入院 時に抗体価の測定を行っていない症例は入院後 に行った初回のマイコプラズマ抗体価とした。 また抗体価の測定病日が一定していないため 7 病日および 10 病日の抗体価の判断は 7 および 10 病日以内の測定で抗体価が 640 倍以上に上昇 している症例数と, 7 および 10 病日以降の測定 で抗体価が 640 倍以下の症例数を比較した。

末梢血白血球数と CRP, 病日は MannWhitney $U$ test を使用し，その他の群間有意差 検定には $\chi$ 二乗検定あるいは Fisher の直接法 を使用し， $p<0.05$ をって統計学的有意差と した。

\section{結 果}

(1) 入院症例の背景

i）年齢分布（図 1)：5歳以下の症例がマイコ プラズマ肺炎全体の $51.8 \%$ を占め, 最少年齢は 7 カ月であった。期間中マイコプラズマ肺炎で 入院した症例は当院に入院した肺炎全体の $28.5 \%$ （83 例/ 291 例）を占め, 5 歳以下では $19.5 \%$ (43 例 $/ 221$ 例） 6 歳以上で $57.1 \%(40$ 例 $/ 70$ 例）を占めた。

ii）平均入院病日と抗菌薬の前投薬の有無（表 2) : 平均入院病日, 抗菌薬の前投薬の割合およ びマクロライド系薬の前投薬の割合は, 5 歳以 下と 6 歳以上ではいずれの点も有意差は認めな かった。

iii）マイコプラズマ肺炎の合併症（表 3) : 5 歳以下の症例では疑いも含め気管支喘息発作や 細気管支炎を合併した症例は 16 例 $(37.2 \%)$ 認 めた。一方 6 歳以上の症例ではマイコプラズマ 肺炎で入院加療中に喘息発作を合併した症例は 認めなかった。

(2) 臨床症状と血液検査所見

i）入院時の咳嗽の性状：マイコプラズマ肺炎 に特徵的とされている乾性咳嗽を入院時に認め た症例は 6 歳以上が $37.5 \%$ （15 例/ 40 例）に対 


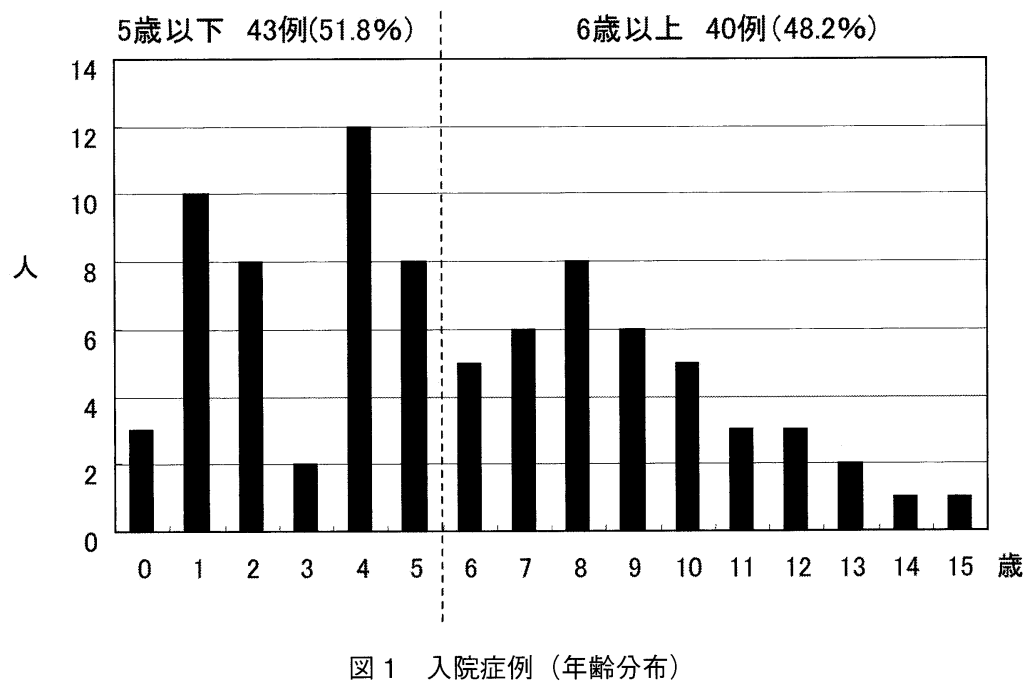

表 2 平均入院病日と抗菌薬の前投薬の比較

\begin{tabular}{|c|c|c|c|c|}
\hline & 症例数 & 平均入院病日 & $\begin{array}{l}\text { 抗菌薬の } \\
\text { 前投薬例数 }\end{array}$ & $\begin{array}{c}\text { マクロライド系薬 } \\
\text { 前投薬例数 }\end{array}$ \\
\hline 5 歳以下 & 43 例 & $6.43 \pm 2.84$ 日 $7 \mathrm{NS}^{*}$ & 30 例 $(70.1 \%) \mathrm{NS}^{*}$ & 14 例 $(32.6 \%) \mathrm{NS}^{*}$ \\
\hline 6 歳以上 & 40 例 & $7.25 \pm 2.45$ 日 $^{ل^{1 \mathrm{~N} S}}$ & 32 例 $(80.0 \%)^{-103}$ & 22 例 $(55.0 \%)$ \\
\hline
\end{tabular}

* NS : no significant difference

表 3 マイコプラズマ肺炎の合併症

\begin{tabular}{|c|c|c|}
\hline 入院時病名 & 5 歳以下 & 6 歳以上 \\
\hline 肺炎 & 27 例 & 39 例 \\
\hline 肺炎＋急性細気管支炎 & 3 例 & \\
\hline 肺炎＋喘息発作 (疑いとして加療) & 13 (6) 例 & \\
\hline 肺炎+脳炎 & & 1 例 \\
\hline 計 & 43 例 & 40 例 \\
\hline
\end{tabular}

し， 5 歳以下ではわずか $10.0 \%(4$ 例 $/ 41$ 例 $)$ であった。 5 歳以下のマイコプラズマ肺炎の入 院時の咳嗽は $90.0 \%$ （37 例/41 例）が湿性咳嗽 であった。

ii）胸部聴診所見：胸部聴診所見は入院時お よび輸液を施行した翌日において検討した。成 人市中肺炎診療ガイドラインではマイコプラズ マ肺炎を含む非定型肺炎は胸部聴診上所見がそ しいことを挙げている。6歳以上の学童におい ても57.5\%（23 例/ 40 例）が肺副雑音を聴取し
なかった。しかし 5 歳以下では肺副雑音を聴取 しなかった症例はわずか $16.3 \%$ (7 例/ 43 例 $)$ であり,入院日と入院翌日を含めると $83.7 \%(36$ 例 $/ 43$ 例）の症例は肺副䧱音を聴取した。

iii）入院時末梢血白血球数（図 2 ), CRP 值（図 3）: 細菌感染症例を含んだ白血球数を比較する と, 5 歳以下の群が 6 歳以上に比べて高く有意 差（P<0.05）を認めた。また白血球数 10,000 / $\mu \mathrm{L}$ 以上の症例数も 5 歳以下に多く認められた $(\mathrm{P}<0.01)$ 。抗菌薬の前投薬の割合は 5 歳以下 では $73.3 \%(22$ 例 $/ 30$ 例 $), 6$ 歳以上では 80.0\%（32 例/ 40 例）と高率であり，5歳以下 と 6 歳以上の前投薬の割合に有意差は認めてい ない。更に細菌感染による影響を除くため洗浄 喀痰培養で細菌感染が証明された症例を除いて 同様の検討を行った。白血球数 $10,000 / \mu \mathrm{L}$ 以上 の症例数は, 細菌感染を除外しても5 歳以下の 乳幼児に有意に高くみられた。しかし抗菌薬の 

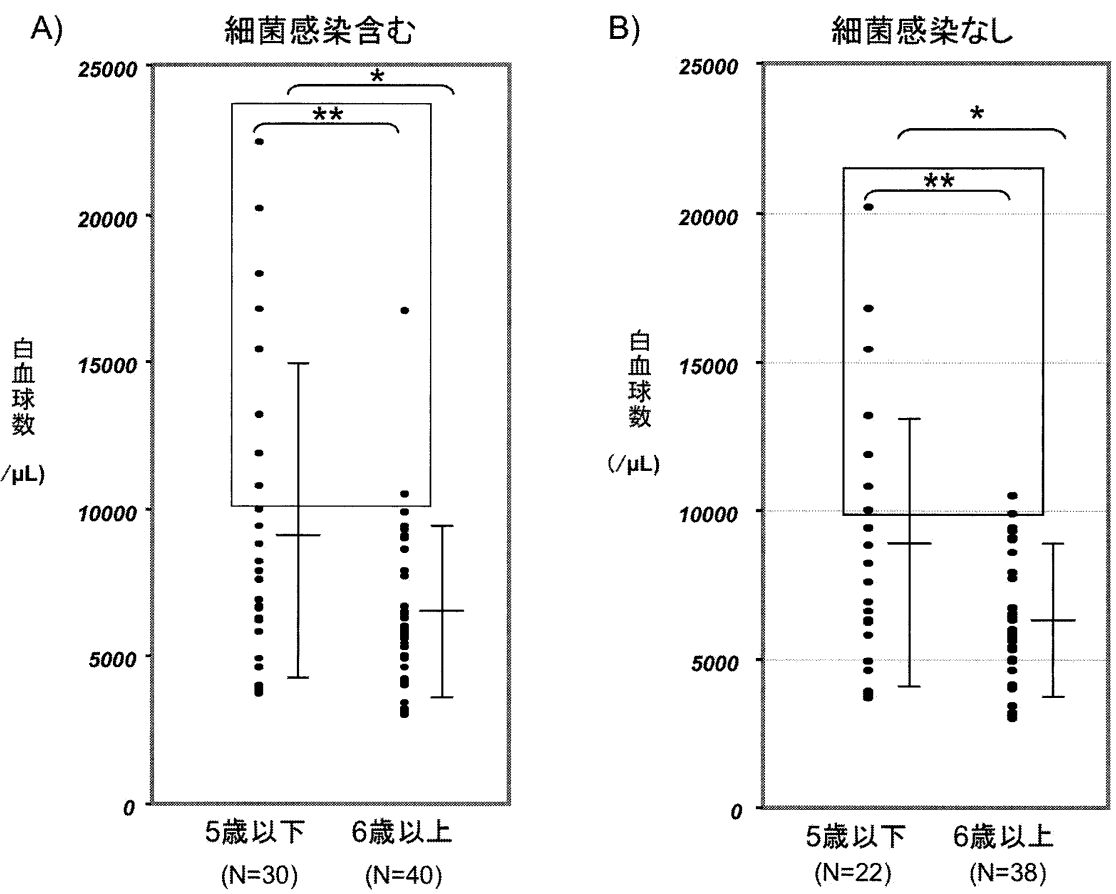

A）細菌感染の症例を含んだ場合の検討では，平均值士標準偏差は 5 歳以下： $9000.0 \pm 5048.8 / \mu \mathrm{L}, 6$ 歳以上 $: 6392.5 \pm 1014.8 / \mu \mathrm{L}$ であり有意差を認めた ( $\left.{ }^{*} P<0.05\right) 。 \square$ り，5 歳以下に有意に多い（** $P<0.01) 。$

B）細菌感染を除外した場合の検討では，平均値士標準偏差は 5 歳以上： $8695.5 \pm 2132.8 / \mu \mathrm{L}, 6$ 歳以上 $: 6392.5 \pm 1014.8 / \mu \mathrm{L}$ であり有意差を認めた ( $\left.{ }^{*} \mathrm{P}<0.05\right) ， \square て ゙$ 囲まれた部分は白血球数 $10,000 / \mu \mathrm{L}$ 以上の症例数の比較であ り, 5 歳以下に有意に多い (** $P<0.01) 。$

図 2 入院時末梢血白血球数

前投薬の割合は 5 歳以下 $72.7 \%(16$ 例 $/ 22$ 例 $)$ 6 歳以上 $84.2 \%(32$ 例 $/ 38$ 例）と高率であり, 5 歳以下と 6 歳以上の群における抗菌薬の前投 薬の割合に有意差は認めないものの，このよう に抗菌薬の前投薬がある場合洗浄喀痰培養によ り有意に細菌が検出されなくても細菌感染の可 能性は否定できない。このため細菌感染のない マイコプラズマ肺炎の評価を行うためには，抗 菌薬の影響がなくGeckler 4, 5 群の喀痰が採取 でき細菌感染を否定できた症例において検討を 行うべきだが，この条件を満たす症例は 5 歳以 下 1 例， 6 歳以上 1 例のため統計学的検討は行 えなかった。CRPは細菌感染症例を含む場合と 除外した場合において年齡に関わらず $0.3 \mathrm{mg} /$ $\mathrm{dl}$ 以下から $10 \mathrm{mg} / \mathrm{dl}$ 以上まで分布した。細菌 感染症例を含んだ検討では 6 歳以上で CRP は 高くなったが $(P<0.05)$, 細菌感染症例を除外 した検討では有意差を認めなかった。抗菌薬の 前投薬の割合は細菌感染を含む全症例（表 2) および細菌感染を除外した症例においても（5 歳以下 $73.3 \%, 6$ 歳以上 $84.2 \% ）$ 有意差は認め られていない。

(3) 細菌感染, ウイルス感染の合併率

細菌感染が証明された症例は，全 83 例中 15 例（18.1\%）であった（図 4)。このうち 5 歳以 下の症例が 13 例（5歳以下 43 例のうちの $30.2 \%), 6$ 歳以上の症例はわずか 2 例（6 歳以 上 40 例のうちの $5.0 \%)$ であり, 細菌感染は 5 

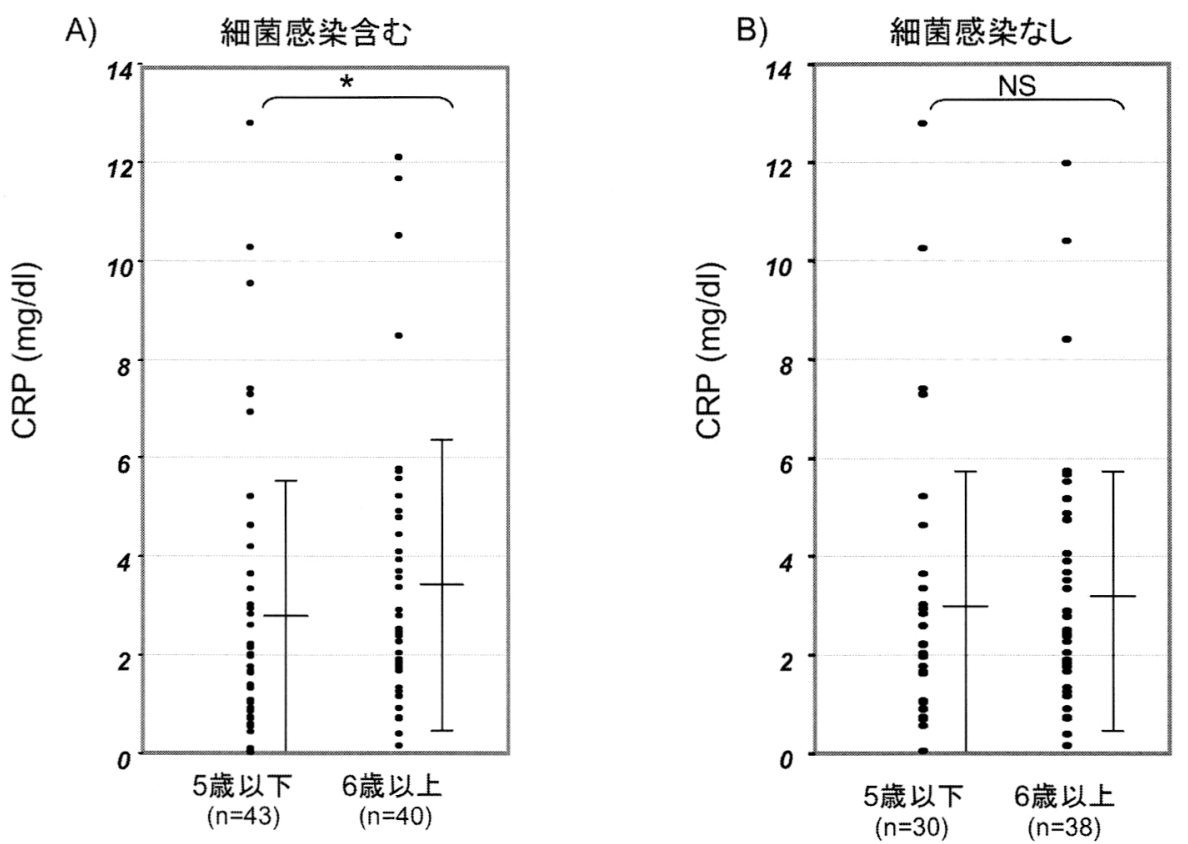

A) 細菌感染の症例を含んだ場合の検討では, 平均值士標準偏差は 5 歳以下:2.68 $\pm 2.97 \mathrm{mg} / \mathrm{dl}, 6$ 歳以上: $3.44 \pm 2.86 \mathrm{mg} / \mathrm{dl}$ であり 6 歳以上が高值であった（ $P$ $<0.05$ )。

B）細菌感染を除外した場合の検討では, 平均值士標準偏差は 5 歳以上 : 2.87 $\pm 3.02 \mathrm{mg} / \mathrm{dl}, 6$ 歳以上 : $3.20 \pm 2.60 \mathrm{mg} / \mathrm{dl}$ であり有意差は認められない。

図 3 入院時 CRP 值

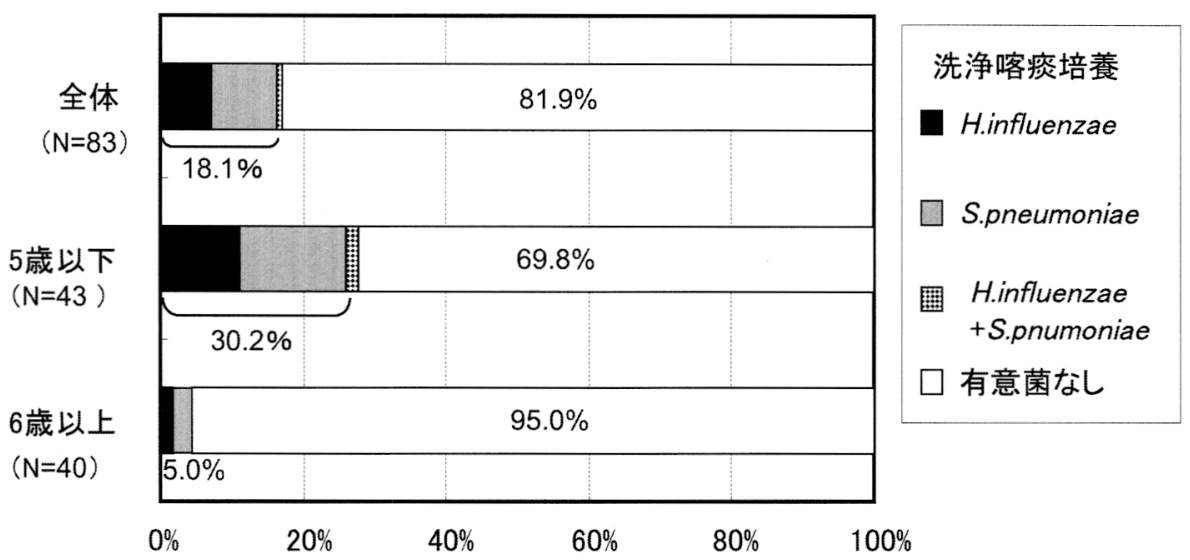

図 4 細菌感染合併率

歳以下の症例に多くみられた。原因菌の内訳は マイコプラズマ肺炎全体ではStreptococcus pneumoniae $9.6 \%$ (8 例/83 例 ), Haemophilus influenzae $7.2 \%$ (6 例/83 例), S.pneumoniae と
H.influenzae の複数菌感染 $1.2 \%(1$ 例 $/ 83$ 例） であった。 5 歳以下で検討するとS.pneumoniae $16.3 \%$ (7 例/43 例), H.influenzae 11.6\%（5 例/ 43 例), S.pneumoniae とH.influenzae の複数菌 
感染 $2.3 \%$ （1 例/ 43 例）であった。6 歳以上で はS.pneumoniae, H.influenzae それぞれ $2.5 \%$ (そ れぞれ 1 例ずつ/40例）であった。喀痰の採取 は入院時に全例に試みたものの，鏡検にて Geckler 1〜3 群の検体であったり痰がからま ず鼻咽頭培養で代用した症例もあり, Geckler 4, 5 群の評価可能な喀痰を採取できた症例は 5 歳 以下で 28 例 $(65.1 \%), 6$ 歳以上で 18 例 (45\%) であった。細菌感染が証明された 5 歳以下 13 例のうち抗菌薬の前投薬は 7 例 $(53.8 \%)$ にみ られ, Geckler 4, 5 群の喀痰が採取され細菌感 染が証明されなかった 15 例は 12 例（80\%）に 抗菌薬の前投薬がみられた。6 歳以上で喀痰を 採取できた 18 例のうち細菌感染は 2 例にみら れ，1例 $(50.0 \%)$ は抗菌薬の前投薬を認めた。
Geckler 4, 5 群の喀痰が採取され細菌感染が証 明されなかった 6 歳以上の 16 例は 14 例 $(87.5 \%)$ に抗菌薬の前投薬がみられた。

ウイルス抗原検査陽性例は 10 例認め, それ ぞれのウイルスの流行期に一致していた。ウイ ルス抗原検査陽性の 10 例中 9 例が 5 歳以下の 症例であった（表 4)。マイコプラズマ肺炎にお ける細菌やウイルスの混合感染合併率(図 5)は, 全体では $25.3 \%(21$ 例/83 例) に認められるが, 5 歳以下で $41.9 \%$ （18 例 $/ 43$ 例）と高率であり, 6 歳以上は $7.5 \%$ (3 例/ 40 例）であった。

(4) マイコプラズマ抗体価 (PA 法) と病日 (図 6)

入院時のマイコプラズマ抗体価が 640 倍以上 の症例は 5 歳以下に多く, 6 歳以上と比較して

表 4 ウイルス抗原検査陽性例

\begin{tabular}{|c|c|c|c|}
\hline ウイルス抗原名 & 年齢 & 入院した月 & マイコプラズマ抗体価 \\
\hline 1. インフルエンザ A, B & 8 歳 & 2 月（2007 年） & 40 倍 $\rightarrow 320$ 倍 \\
\hline 2. インフルエンザA & 0 歳 & 3 月（2007 年） & 1,280 倍 \\
\hline 3. RS ウイルス & 1 歳 & 12 月 & 640 倍 \\
\hline 4. & 1 歳 & 12 月 & 1,280 倍 \\
\hline 5. & 2 歳 & 1 月（2007 年） & 320 倍 $\rightarrow 640$ 倍 \\
\hline 6. & 4 歳 & 1 月（2007 年） & 640 倍 \\
\hline 7. & 5 歳 & 12 月 & 40 倍 $\rightarrow 2,560$ 倍 \\
\hline 8. アデノウイルス & 1 歳 & 9 月 & 2,560 倍 \\
\hline 9.（咽頭） & 1 歳 & 9 月 & 40 倍 $\rightarrow 1,280$ 倍 \\
\hline 10. & 5 歳 & 9 月 & 40 倍以下 $\rightarrow 2,560$ 倍 \\
\hline
\end{tabular}

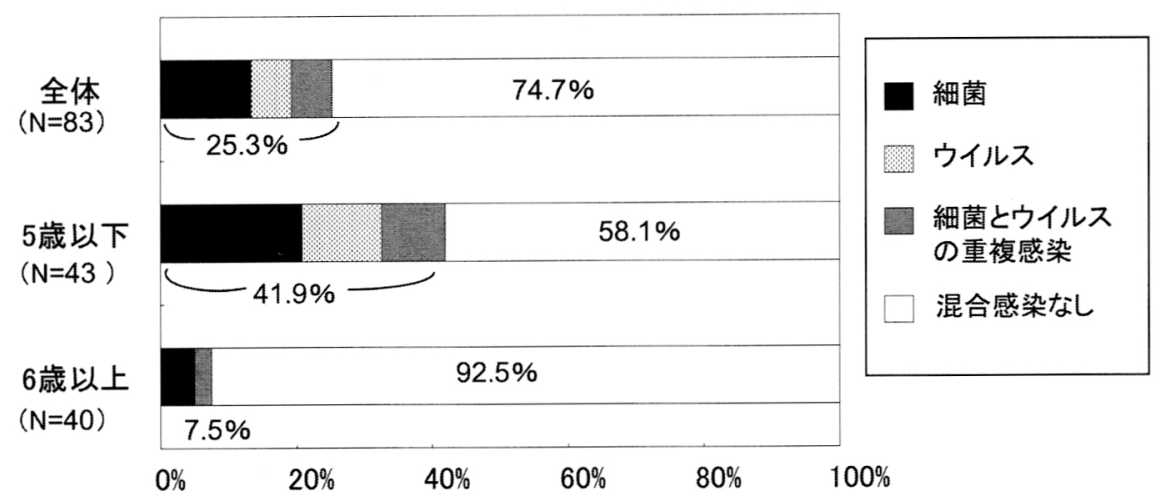

図 5 細菌, ウイルスの混合感染合併率 


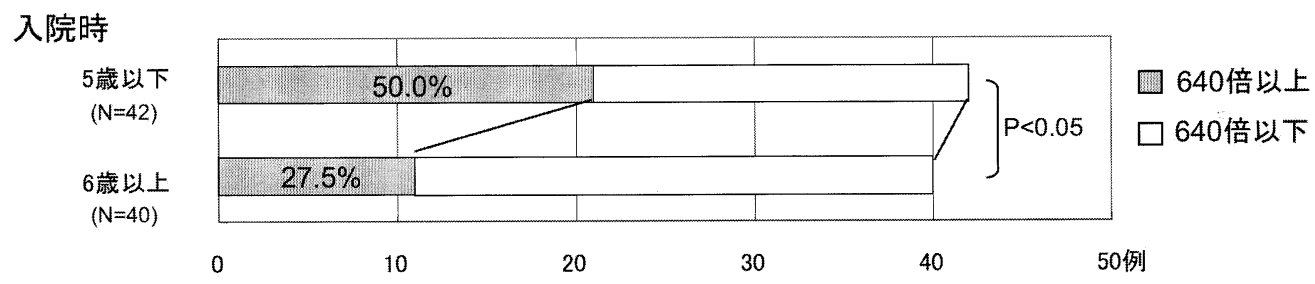

7 病日

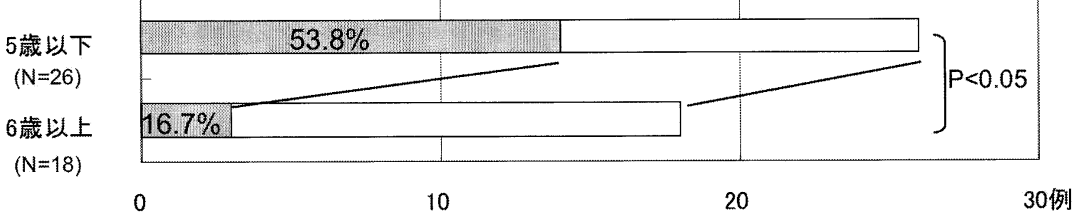

\section{0病日}

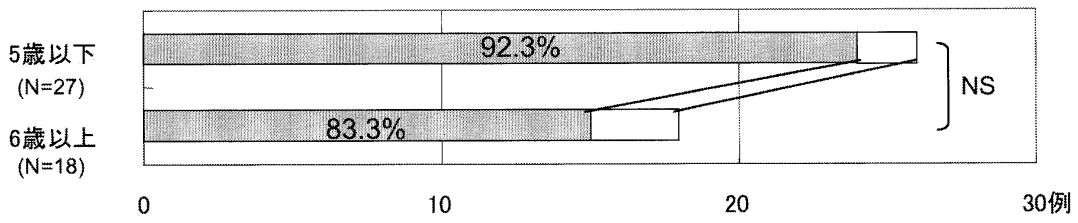

入院時の抗体価平均測定病日は 5 歳以下: $6.50 \pm 2.92$ 日, 6 歳以上: $7.33 \pm 2.61$ 日であり，有意差は認めない。

図 6 年齢によるマイコプラズマ抗体価（PA 法）と病日の比較

有意差 $(P<0.05)$ が認められた。更に 7 病日 の時点で抗体価が 640 倍以上に上昇している症 例数も5 歳以下で有意 $(P<0.05)$ に多かった。 しかし 10 病日になると有意差は認められな かった。抗体価の上昇が遅く診断に苦慮した症 例は第 11 病日で 160 倍までしか上昇せず第 15 病日になり 640 倍まで上昇した 1 歳の症例であ る。6 歳以上の症例においても第 10 病日で 160 倍, 第 13 病日 320 倍, 第 23 病日で 1,280 倍ま で上昇した 9 歳の症例があった。また低年齢巟 のマイコプラズマ抗体価の上昇については， 7 カ月児の症例が第 10 病日 2,560 倍まで上昇し た。

\section{考察}

マイコプラズマ感染症の診断は, 血清診断法 としては現在 PA 法が広く用いられている。PA 法は主として IgM を検出する方法であり, ペ
ア血清で 4 倍以上の上昇あるいは単一血清で 640 倍以上の抗体価を認めた場合を診断の基準

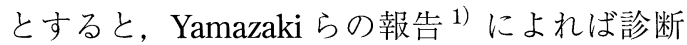
特異性は前者が $100 \%$ ，後者が $99.3 \%$ あるる。 しかし今回の抗体価の検討では, 640 倍以上と いうポイントで区切ると入院時には 5 歳以上で $50.0 \%$ の症例， 6 歳以上では $27.5 \%$ の症例しか 上述の診断基準を満たしておらず，7病日では 6 歳以上の症例はわずか $16.7 \%$ しか基準を満た さない。7 病日以前にマイコプラズマ抗体価を 測定すればペア血清で抗体価の上昇が証明され る可能性があるが，7病日以前に採血を行い抗 体価を測定することは臨床の現場においては頻 度は少ないと考えられる。また 15 病日を超え て初めて診断された症例も散見され, PA法に よる抗体価上昇には日数がかかり確定診断が遅 れることが示唆される。すなわち治療を選択す るための急性期の診断法としては必ずしも十分 
とはいえない。またマイコプラズマ特異的 IgM 抗体を迅速に検出する簡易イムノクロマトグラ フ法（イムノカードマイコプラズマ抗体, 以下 IC, Meridian ーテイエフビー）は成田の報告 ${ }^{2)}$ では，感染後最長 527 日目でも陽性と判定され たが，PA 法あるいは ELISA 法で非感染と判断 される例がみられている。更に健常成人血清 124 検体中 PA 法では 320 倍が最高值で 3 例 (2.4\%) のみ存在したのに対し，IC 法では検索 した 25 例中 9 例 $(36 \%)$ が陽性であり，その うち ELISA 法にては少なくとも 6 例が急性感 染は否定的であった。IC 法はあくまでも定性 法であり，その陽性結果は IgM 抗体の存在を 意味するものではあるがそれが急性感染の存在 を確定するものではないと, 診断上の注意を喚 起している。マイコプラズマ特異的 $\operatorname{IgM}, \operatorname{IgA}$, $\operatorname{IgG}$ 抗体を分別して検出する ELISA 法はその有 用性が報告 ${ }^{3)}$ されているものの, 現時点ではま だ保険収載されていない。また培養，PCRなど で菌体を直接証明する方法もマイコプラズマ感 染症においては一般的ではない。このようにマ イコプラズマ感染症の診断において, 早期に診 断できる感度のよい診断法は現時点では存在し ないのが実情である。

成人市中肺炎診療ガイドラインでは表 1 に示 すように抗体価に頼らず臨床症状と迅速検査に よる細菌感染の除外，一般血液検查を組み合わ せ非定型肺炎を予測する方法を記載している。 小児においても頑固な痰のからまない晐, 胸部 聴診所見が乏しい，末梢血白血球数が 10,000/ $\mu \mathrm{L}$ 未満であるという所見はマイコプラズマ感 染症の臨床的特徵とされている。6 歳以上の肺 炎の原因はマイコプラズマが最も多く ${ }^{4)}$, 小巟 肺炎においても 6 歳以上で乾性咳嗽, 胸部聴診 所見がそしい, 未梢血白血球数が $10,000 / \mu \mathrm{L}$ 末 満, 更に他の所見を組み合わせスコアリングし, 細菌性肺炎と非定型肺炎を鑑別する方法の有用 性が報告 ${ }^{5)}$ されている。しかし細菌感染やウイ
ルス感染の多い 5 歳以下では, マイコプラズマ 肺炎の診断にはしばしば苦慮する。そこで今回 5 歳以下の乳幼児に成人の市中肺炎診療ガイド ラインに記載されている臨床的特徴は合致する のか否か, 6 歳以上との相違点が認められるの か検討を行った。

2005 年度マイコプラズマ肺炎のため当院に入 院した症例は肺炎全体のわずか $3.5 \%{ }^{6)}$ (14 例/ 397 例）であったが，2006 年度は $28.5 \%$ を占め 当院周辺の千葉市でマイコプラズマ感染症の流 行がみられた。最少年齢 7 カ月をはじめとして 5 歳以下の症例が $51.8 \%$ を占め, マイコプラズ マ感染症流行期には乳幼児も罹患することがわ かる。今回の検討では, 5 歳以下と 6 歳以上の マイコプラズマ肺炎の病態を検討する上で影響 が考えられる入院までの日数, 抗菌薬の前投薬 の割合およびマクロライド系薬の前投薬の割合 はいずれも有意差は認めなかった。しかし咳嗽 の性状は 5 歳以下の乳幼览で受診時特徵的な乾 性咳嗽を認めたのはわずか $10.0 \%$ であり， $90.0 \%$ が湿性咳嗽であった。胸部聴診所見も 5 歳以下の乳幼児では, 受診時および点滴が入っ た翌日も含めると $83.7 \%$ に肺副雑音を認めた。 喘息発作の合併を除く末梢血白血球数の検討で は, 抗菌薬の前投薬のため細菌感染の評価に限 界があるが洗浄喀痰培養で証明された細菌の二 次感染例を除外しても，5歳以下は 6 歳以上に 比べて有意に高く白血球数 $10,000 / \mu \mathrm{L}$ 以上の症 例も多く認めた。CRPの分布は年齢に関わらず 一定の傾向は認めず，細菌の二次感染例を除外 すれば年齢による有意差は認めなかった。以上 より 5 歳以下の乳幼児のマイコプラズマ肺炎は 成人とは異なった臨床像を認め, 咳嗽の性状や 肺副雑音の有無, 末梢血白血球数から推測する ことは困難と考えられる。このように成人と異 なった臨床像を示す原因として，5歳以下の乳 幼児のマイコプラズマ肺炎では細菌の二次感染 やウイルスの混合感染が多いため臨床像が修飾 
されていることが考えられる。今回の検討では 5 歳以下の乳幼児の $41.9 \%$ に細菌やウイルスの 混合感染が証明されている。更に抗菌薬の前投 薬の割合が高率であることを考慮すると, 抗菌 薬の前投薬をうけ洗浄喀痰培養による原因菌の 基準を満たさなかった症例の中にも細菌感染を 合併している症例が含まれている可能性があ る。ウイルス感染についても今回抗原検査を全 例に施行していないことやウイルス分離法を併 用していないことから，今後前方視的な検討を 行えばウイルス感染の確率や 6 歳以上において もウイルス感染の確率が上昇する可能性があ る。また肺炎に加え病名として気管支喘息発作, 細気管支炎の診断が併記されている症例が 5 歳 以下 43 例中 16 例みられるが，6歳以上の症例 には認めなかった。永山らは年少児のマイコプ ラズマ感染では多くが喘鳴を呈することを指摘 しており7), これは気道狭窄症状として今回の 結果と一致する所見と考えられる。5 歳以下の マイコプラズマ肺炎に喘息発作や細気管支炎の 合併が多いことも, 湿性咳嗽や肺副雑音の要因 と考えている。

抗体価の検討では, 5 歳以上の症例が 6 歳以 上に比較して入院時および7病日の抗体価が 640 倍以上上昇している症例数を多く認めた。 発熱を認めた日を 1 病日としたが, 多くの症例 が咳嗽を数日前から認めており発症日の決め方 で結果が異なる可能性も考えられる。しかし少 なくとも低年齢児においてもマイコプラズマに 罹患すれば抗体価が上昇することは明らかであ ろう。

今回治療についての検討は行っていないが, マイコプラズマは近年マクロライド耐性マイコプ ラズマが報告されている ${ }^{8)}$ 。マクロライド耐性 マイコプラズマは, 細菌の薬剤感受性検査のよ うに数日で結果が判明できるものではない。また clarithromycin (CAM) や erythromycin (EM) は小児気管支肺感染症の主要な原因菌である
H.influenzae P.pneumoniaeには効果がそしく, azithromycin (AZM) \& S.pneumoniaeには効 果がそしい。このため臨床の現場でマイコプラ ズマ肺炎を疑ってマクロライド系薬で治療を開 始したものの効果がない場合, マクロライド耐 性マイコプラズマなのか, 細菌の二次感染が併 発しているのか, そして診断が正しいのか判断 が難しくなる。マイコプラズマ抗体価の上昇も 遅く, 細菌培養ができない施設では推定で治療 を選択せざるを得ず不必要な抗菌薬の使用につ ながることが懸念される。

以上 5 歳以下の乳幼览のマイコプラズマ肺炎 の臨床像を検討した。乳幼巟のマイコプラズマ 肺炎はウイルスや細菌の混合感染および気管支 喘息の合併が多く, 臨床像は成人のマイコプラ ズマ肺炎のような典型例は少ない。よって臨床 像より推測することは困難と考えられ, 今後早 期診断可能でかつ感度のよい検査法の保険収載 が望まれる。

\section{文献}

1) Yamazaki, T., Narita, M., Sakai, T.: Comparison of PCR for sputum samples obtained by induced cough and serologic tests for diagnosis of Mycoplasma pneumoniae infection in children. Clin. Vac. Immunol. 13: 708-710, 2006.

2）成田光生：マイコプラズマ感染症診断に扔け る IgM 抗体迅速検出法の有用性と限界, 感染 症誌, 81: 149-154, 2007.

3）成田光生：小児期マイコプラズマ感染症診断 におけるマイコプラズマ特異的 IgG, IgA, IgM 抗体検出 enzyme-linked immunosorbent assay キットの有用性に関する検討, 感染症誌, 79: 457-463, 2005.

4) 中村 明: 気管支肺感染症病因診断の問題点 —EBMの時代を迎えて, 日児誌, 107: 10671073, 2003.

5）永井文栄, 大嶋寛子, 石和田稔彦, 他：小児 肺炎におけるスコアリングを用いた細菌性肺 炎と非定型肺炎の鑑別の試み, 小児感染免疫, 19: 104-105, 2007.

6）武田紳江, 黒崎知道, 有馬聖永, 他 : 小児肺 
炎における初期抗菌薬としての Ampicillin の有 効性について, 日児誌, 112: 1081-1087, 2008.

7) Nagayama, Y., Sakurai, N., Yamamoto, K., et al: Isolation of Mycoplasma pneumoniae from children with lower respiratory tract infections.
J. Infect. Dis. 157: 911-917, 1988.

8) Suzuki, S., Yamazaki, T., Narita, M., et al: Clinical evaluation of Macrolide-resistant Mycoplasma pneumoniae. Antimicrob. Agents. Chemother. 50: 709-712, 2006. 